KILAT

Vol. 10, No. 1, April 2021, P-ISSN 2089-1245, E-ISSN 2655-4925

DOI: https://doi.org/10.33322/kilat.v10i1.1200

\title{
Double Exponential Smoothing Berimputasi LOCF Dan Linear Interpolation Dalam Akurasi Peramalan Harga Harian Emas
}

\author{
Riki Ruli A. Siregar*1, Taufik Djatna ${ }^{2}$, Sergius Sarmose Manggara Putra Manullang, \\ Irwansyah Saputra ${ }^{4}$ \\ 1, 2, 4 Department of Computer Science, IPB University, Indonesia \\ ${ }^{3}$ Fakultas Telematika Energi, Institut Teknologi PLN, Jakarta Indonesia \\ rulirikisiregar@apps.ipb.ac.id
}

\begin{abstract}
Gold is another kind of investment that often experiences price change, mostly every day. Because of its price fluctuation, forecasting is needed to help the investor in investment decision making. But during this Coronavirus Disease 2019 (Covid-19), the gold price is fluctuating extremely than the past 4 years so a better forecasting method approached and analysis technique is needed due to this case. Double Exponential Smoothing method is chosen to forecast this daily gold price. On the other hand, there are so many missing values spreading around the main dataset so the imputation method is needed too, Last Observation Carried Forward (LOCF) and linear interpolation are chosen for imputing the missing values. In this research, the main dataset was split into 3 (three) datasets, which are Precovid-19 (before Covid-19, used only for visualizing the actual fluctuation condition during this pandemic), Incovid-19 (during Covid-19 based on the date where the first Covid-19 case occurred in Indonesia), and Combination (a binding dataset of Pracovid-19 and Incovid-19). Although Incovid-19's MAPE value is higher than Pracovid-19 and Combination's MAPE values, in evaluation session showed that Incovid19 's MAPE of forecast results has the lowest value rather than Combination's MAPE of forecast results, so the conclusion of this research is Incovid-19 dataset with LOCF imputation is the most adaptive with the actual condition and it is used to forecast the daily gold price until the last period of the main dataset then.
\end{abstract}

Keywords: Double Exponential Smoothing, Last Observation Carried Forward (LOCF), linear interpolation, daily gold price, Covid-19

\begin{abstract}
ABSTRAK
Emas adalah salah satu jenis investasi yang sering mengalami perubahan harga, umumnya setiap hari. Karena faktor fluktuasi inilah diperlukannya peramalan harga emas untuk membantu para investor dalam pengambilan keputusan. Namun selama pandemi Coronavirus Disease 2019 (Covid-19) ini harga emas mengalami fluktuasi yang lebih ekstrim dibanding 4 tahun terakhir sehingga diperlukannya pendekatan metode peramalan dan analisis yang tepat. Metode peramalan yang dipilih adalah Double Exponential Smoothing (DES). Selain itu, ditemukan banyak sebaran missing values sehingga diperlukannya imputasi, maka dipilih metode Last Observation Carried Forward (LOCF) dan linear interpolation. Dalam penelitian ini dataset utama dibagi ke dalam 3 (jenis) dataset, yaitu; Pracovid-19 (sebelum terjadinya Covid-19, digunakan hanya untuk visualisasi fluktuasi ekstrem dari pandemi Covid19), Incovid-19 (selama terjadinya Covid-19 berdasarkan informasi tanggal kasus Covid-19 pertama di Indonesia), dan Kombinasi (gabungan dataset Pracovid-19 dan Incovid-19). Dalam peramalan, Incovid19 memiliki MAPE lebih besar dibanding Pracovid-19 dan Kombinasi, namun hasil evaluasi menunjukkan peramalan Incovid-19 memiliki hasil MAPE terendah sehingga Incovid-19 dengan imputasi LOCF dipilih menjadi dataset dengan peramalan paling adaptif di lapangan dan digunakan untuk meramalkan harga harian emas sampai rekam data paling akhir dari dataset utama.
\end{abstract}

Kata kunci: Double Exponential Smoothing, Last Observation Carried Forward (LOCF), linear interpolation, harga harian emas, Covid-19 


\section{PENDAHULUAN}

Emas adalah salah satu logam mulia yang paling dicari dan mempunyai nilai ekonomis tinggi di mata masyarakat hingga saat ini. Emas telah dianggap sebagai komoditas yang sangat berharga selama ribuan tahun dan harga emas diikuti secara luas di pasar keuangan di seluruh dunia [1] [2]. Emas memiliki beberapa peran penting, seperti pengganti nilai mata uang ketika memerlukan dana yang lebih besar nantinya [3], memiliki nilai prestise dan filosofi di lingkungan sosial, budaya, keagamaan, dan bermanfaat dalam bidang industri misalnya pada perusahaan elektronik emas digunakan sebagai salah satu bahan baku dalam papan sirkuit dan komponen elektaronik lainnya karena bersifat konduktor yang baik pada perangkat bertegangan rendah dan arus rendah serta cukup kuat terhadap efek korosi terutama jika dicampurkan dengan sejumlah kecil nikel/kobalt [4]

Ditemukan sistem korelasi yang kuat antara harga emas dan nilai tukar. Emas memiliki peran penting juga dalam sistem moneter suatu negara [5]. Misalnya emas menjadi cadangan devisa bagi suatu negara sehingga efek inflasi bisa direduksi. Selain itu, investasi emas merupakan salah satu jenis investasi yang paling aman dan menjanjikan bagi para investor [6]. Tak jarang investor juga memerlukan adanya prediksi harga emas agar bisa membeli atau menjual emasnya untuk mendapatkan untung lebih. Karena hal tersebutlah kegiatan memprediksi harga emas menjadi signifikan dan penting bagi para investor [7]. Dari beberapa kondisi perkembangan emas, bahwa prediksi harga emas menjadi sangat penting dalam perencanaan bisnis dan dan proses pengambilan keputusan [8] [9] [10] [11].

Pandemi Coronavirus Disease-19 (Covid-19) yang mulai masuk ke Indonesia sejak 2 Maret 2020 [12] sangat mempengaruhi fluktuasi harga harian emas hingga beberapa media konvensional dan media elektronik menyarankan untuk meminimalisir melakukan investasi emas terutama jika harga melonjak naik dan belum stabil [13] [14]. Selama pandemi ini, namun fluktuasi selama pandemi ini tidak menjamin keuntungan besar [15]. Dengan trend yang terus naik, diprediksi ahli akan menembus harga Rp. 1.000.000/gram, bahkan disarankan untuk tunda membeli emas sebelum angka harga emas turun ke harga Rp.800.000/gram [16]. Ketidakpastian harga emas di tengah pandemi ini mempengaruhi minat pembelian para investor, terutama investor menengah ke bawah dan berekonomi terdampak pandemi ini. Tentu hal ini merisaukan apalagi jika sang investor tidak memiliki proyeksi akurat mengenai harga emas periode berikutnya [17]. Maka dari itu dimunculkanlah pemikiran untuk melakukan peramalan harga harian emas [18] [19] [20].

Metode yang akan digunakan dalam meramalkan harga harian emas adalah metode Double Exponential Smoothing (DES) [21] [22], dengan data yang diambil adalah data harga emas harian PT. Aneka Tambang yang didapatkan dari website logammulia.com [23], terhitung sejak tanggal 28 Desember 2015 hingga 24 Juni 2020. Alasan dibalik pemilihan DES adalah adalah karena pola harga harian emas menunjukkan pola trend non-musiman sejak tahun 2015 hingga 2020 meskipun memiliki banyak fluktuasi, terutama di tahun 2020 yang mana adalah tahun awal pandemik Covid19 ini. Kendala yang ditemukan dalam dataset ini adalah ditemukannya banyak missing values, sehingga diperlukannya pembersihan data dan proses imputasi. Imputasi yang akan digunakan dalam penelitian ini adalah imputasi Last Observation Carried Forward (LOCF) [24] [25]dan imputasi linear interpolation sederhana [26] [27]. Baik imputasi LOCF dan linear interpolation dipilih karena keduanya dapat diterapkan untuk semua jenis pola data, namun lebih optimal untuk pola data nonmusiman [28]. Setelah dilakukan imputasi, data akan diproses ke dalam DES dan linear interpolation dan akan diuji dataset berimputasi yang memiliki tingkat error terendah beserta evaluasi hasil peramalan dari setiap dataset. 


\section{KILAT}

Vol. 10, No. 1, April 2021, P-ISSN 2089-1245, E-ISSN 2655-4925

DOI: https://doi.org/10.33322/kilat.v10i1.1200

\subsection{Kajian Pustaka}

Kajian investasi pada emas dengan mengetahu model sebagai acuan keputusan kapan harus menjual dan membeli dilakukan di Malaysia di triwulan pertama tahun 2017 [29]. Penelitian yang dilakukan dengan kemungkinan perubahan harga dengan menggunakan metode peramalan Non Linear Prediction (NLP) dan metode Box-Jenkins. Dari hasil perbandingan performa prediksi antara model NLP dan Box-Jenkins berdasarkan MAPE digunakan dan sebagai hasilnya, NLP menunjukkan performa prediksi yang lebih baik. Penelitian selanjutnya [30] [31] dalam memprediksi data dengan time series pada metode Double Exponential Smoothing menggabungkan penghitungan faktor pembobotan dalam Weighted Moving Average (WEMA) dan mengimplementasikan hasilnya dengan metode DES. Metode yang diusulkan akan diuji pada data Jakarta Stock Exchange (JKSE) dengan akurasi yang unggul. Penelitian dengan perbandingan dari regresi dan model single, double da tree exponential mampu dalam meramalkan dalam waktu non musiman [32]. Kajian lain pada peramalan jumlah wisatawan dengan menggunakan metode DES dan WEMA, kedua metode tersebut mampu menganalisis data berpola tren tanpa asumsi sehingga memudahkan dalam proses analisis. Selain itu, kedua metode pada penelitian sebelumnya mampu menghasilkan akurasi peramalan yang kecil. Penggunaan metode imputasi LOCF dilakukan untuk memasukkan data uji klinis yang mempunyai missing value dari parameter yang ada dapat dengan tepat di analisis [33]. penelitian yang diusulkan menciptakan model untuk penghitungan risiko situasi politik, keamanan dengan menggunakan negara dan dampak ekonomi khusus peristiwa sebagai aspek [34]. Hasil yang diperoleh dengan Teknik regresi dari berbagai macam data untuk mengidentifikasi fitur yang paling berpengaruh dari harga emas, mempunyai kontribusi dari intensitasi peristiwa yang dianggap sebagai variabel potensi dari dampak situasi dalam periode waktu tertentu.

\section{METODE}

Tahapan penelitian yang digunakan dalam penelitian ini adalah CRISP-DM (Cross-Industry Standard Process Model for Data Mining). Berikut tahapannya:

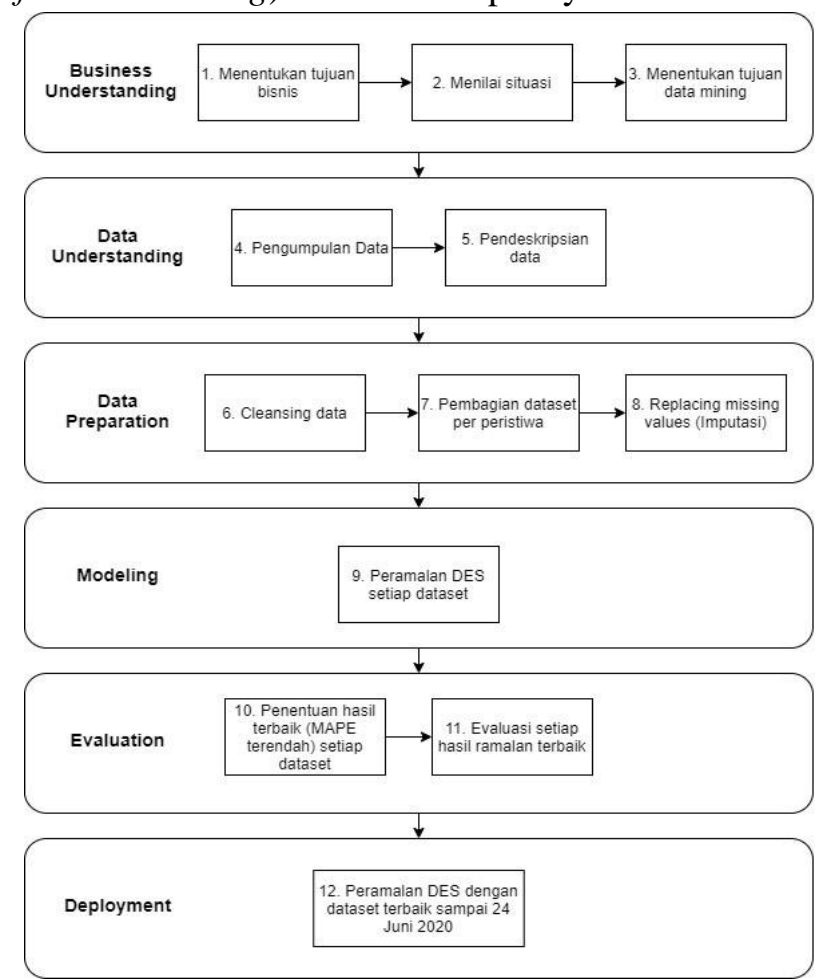

Gambar 1 Diagram CRISP-DM) [35] 


\subsection{Business Understanding}

a. Menentukan Tujuan Bisnis

Tujuan bisnis dilakukannya penelitian ini adalah untuk mengetahui perkiraan harga emas Antam di hari berikutnya.

b. Menilai Situasi

Penelitian ini berkaitan dengan kebiasaan umum masyarakat yang dalam melakukan investasi emas Antam tidak melakukan prediksi sama sekali sehingga mempengaruhi manajemen keuangan dan pengambilan keputusan mereka untuk melakukan investasi emas, misalnya hanya menunggu dan berharap ada penurunan harga emas di hari berikutnya atau terburu-buru melakukan investasi emas di hari itu juga sedangkan keesokan harinya memiliki kemungkinan turun (meskipun dari banyak ahli mengatakan naikturunnya emas tetap akan menguntungkan sebagai investasi, tetapi daya beli masyarakat masih bergantung pada naik-turunnya emas di hari itu).

c. Menentukan Tujuan Data Mining

Tujuan dari penelitian ini adalah untuk mengetahui pengaruh metode imputasi terhadap tingkat akurasi peramalan serta mengetahui prediksi harga harian emas berikutnya melalui Double Exponential Smoothing.

\subsection{Data Understanding}

a. Pengumpulan Data

Data yang dikumpulkan adalah data time series harian harga emas Antam beserta tanggal update harga hariannya, terhitung dari tanggal 28 Desember 2015 hingga 24 Juni 2020. Data harga harian emas Antam yang terkumpul sebanyak 1641 data yang diperoleh dari website logammulia.com. Data diinput kedalam RStudio. Berikut adalah hasil observasi mengenai rekam data yang ada:

Tabel 1. Hasil observasi data mentah

\begin{tabular}{|c|c|c|c|}
\hline Hari & Jumlah Rekam Data & Missing Values & Data Terisi \\
\hline Senin & 235 & 16 & 219 \\
\hline Selasa & 235 & 14 & 221 \\
\hline Rabu & 235 & 14 & 221 \\
\hline Kamis & 234 & 11 & 223 \\
\hline Jumat & 234 & 17 & 217 \\
\hline Sabtu & 234 & 25 & 209 \\
\hline Minggu & 234 & 217 & 17 \\
\hline Total & 1641 & 314 & 1327 \\
\hline
\end{tabular}

b. Pendeskripsian Data

Atribut "hari" merupakan hari dimana harga di-update (tipe data character), atribut "tanggal" merupakan data update harga harian (tipe data date), atribut "harga" merupakan data harian harga emas Antam (tipe data numeric) Pendeskripsian dilakukan di dalam RStudio. 


\section{KILAT}

Vol. 10, No. 1, April 2021, P-ISSN 2089-1245, E-ISSN 2655-4925

DOI: https://doi.org/10.33322/kilat.v10i1.1200

\subsection{Data Preparation}

a. Pembersihan Data (Cleansing Data)

Berdasarkan Tabel 1, diketahui pada rekam data hari minggu memiliki sejumlah masalah didalamnya. Beberapa diantaranya adalah jumlah data terisi sangat kecil dibanding missing values, yaitu sebesar 217 missing values dan 17 data terisi dengan persebaran data terisi dan data kosong sangat acak. Selain itu, diketahui pula nilai pada hari minggu mengikuti nilai pada periode sebelumnya (yaitu hari sabtu). Hal ini akan bermasalah jika nilai pada hari sabtu tidak diketahui juga sehingga imputasi pada hari minggu tidak dapat dilakukan. Berdasarkan permasalahan tersebut, maka diputuskan dilakukan penghapusan terhadap 234 rekam data hari minggu karena rekam data yang ada tidak merepresentasikan data aktual hari minggu, sehingga total rekam data menjadi 1407 rekam data.

b. Pembagian Dataset per Peristiwa

Setelah dilakukan imputasi, data time series dilakukan pembagian dataset dengan ketentuan sebagai berikut:

1. Dataset Pracovid-19 (28 Desember 2015- 29 Februari 2020), untuk meramalkan 14 periode kedepan (2 minggu pertama Covid-19)

2. Dataset Incovid-19 (2 Maret 2020- 18 Juni 2020), untuk meramalkan 5 periode kedepan

3. Dataset Kombinasi (28 Desember 2015-18 Juni 2020), untuk meramalkan 5 periode kedepan

Pemilihan dataset Incovid-19 dimulai pada 2 Maret 2020 berdasarkan tanggal

pengumuman Pemerintah Republik Indonesia mengenai dinyatakan adanya kasus pertama penderita Covid-19 di Indonesia [12]. 14 periode hasil peramalan untuk Pracovid-19 ditujukan hanya untuk memvisualisasikan data apakah benar selama 14 hari pertama terjadinya Covid-19 membuat harga emas memiliki gejolak fluktuasi yang ekstrim. Sedangkan untuk 5 periode hasil peramalan Incovid-19 dan Kombinasi memiliki tujuan yang berbeda, yaitu untuk peramalan dan untuk mengevaluasi apakah kemampuan peramalan Double Exponential Smoothing cukup mendekati data aktual atau belum. Pada pembagian data ini, data tanggal 2 Maret-17 Maret 2020 akan digunakan sebagai data evaluasi hasil peramalan Pracovid-19 dan data tanggal 19 Juni-24 Juni 2020 akan digunakan sebagai data evaluasi hasil peramalan Incovid-19 dan Kombinasi.

\section{c. Replacing Missing values}

Masih ditemukan beberapa missing values pada data time series harga harian emas Antam. Berdasarkan observasi, missing values memiliki posisi yang tidak berpola/tidak teratur (nilai kosong secara acak), ada beberapa yang kosong dengan jangka waktu beberapa hari kedepan, ada juga yang beberapa minggu kemudian baru ditemukan missing values lagi sehingga missing values disini terhitung kedalam kategori MCAR dan MCAR dapat dilakukan imputasi [36] [37] [38]. Imputasi diterapkan untuk mengisi data yang kosong dengan perkiraan harga.

Metode imputasi yang dipilih adalah LOCF dan linear interpolation. LOCF cukup mensubstitusikan nilai periode sebelumnya kedalam missing value namun memiliki kelemahan yaitu tingkat gap nilai antar periode yang tergantung variasi antar data periode tersebut [39]. Sedangkan Linear interpolation merupakan salah satu metode imputasi yang umum dipakai pada model data univariat [40] dengan cara melakukan pencarian nilai tengah yang akan dijadikan nilai dari missing value. Dimana terdapat missing value, pada 
linear interpolation digunakan [41]. Linear Interpolation sederhana bisa diterapkan untuk mengisi data non-musiman yang kosong [42]. Berikut persamaannya [43]:

$$
f 1(X)=f(X 0)+\frac{f(X 1)-f(X 0)}{(X 1-X 0)}(X-X 0)
$$

Dimana:

$$
\begin{array}{ccl}
\mathrm{X} & : & \text { periode yang nilainya dicari } \\
X 0 & : & 1 \text { periode sebelum } \mathrm{X} \\
X 1 & : & 1 \text { periode setelah } \mathrm{X} \\
f 1(\mathrm{X}) & : & \text { Nilai fungsi dari periode yang dicari } \\
f(X 0) & : & \text { Nilai fungsi dari 1 periode sebelum } \mathrm{X} \\
f(X 1) & : & \text { Nilai fungsi dari 1 periode setelah } \mathrm{X}
\end{array}
$$

\subsection{Modeling}

Berikut adalah pemodelan data mining dari penelitian:

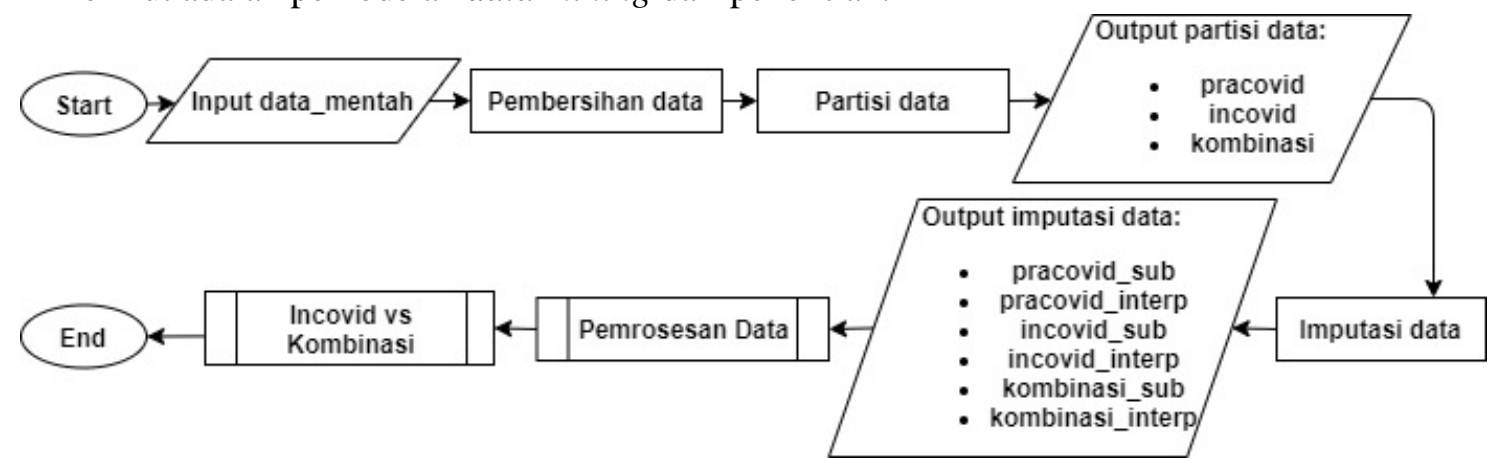

Gambar 2. Alur General Process 
KILAT

Vol. 10, No. 1, April 2021, P-ISSN 2089-1245, E-ISSN 2655-4925

DOI: https://doi.org/10.33322/kilat.v10i1.1200

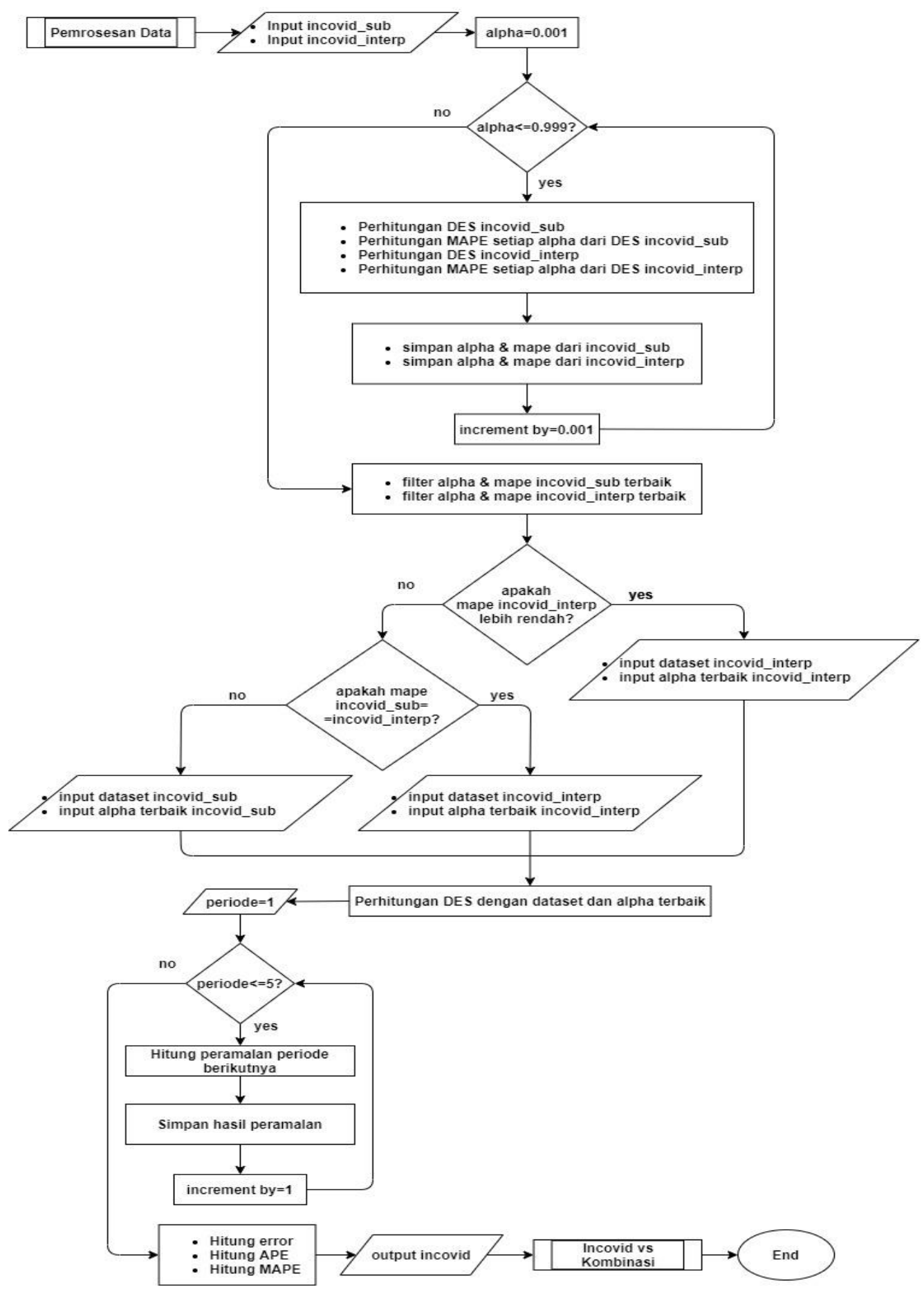

Gambar 3 Alur Double Exponential Smoothing 


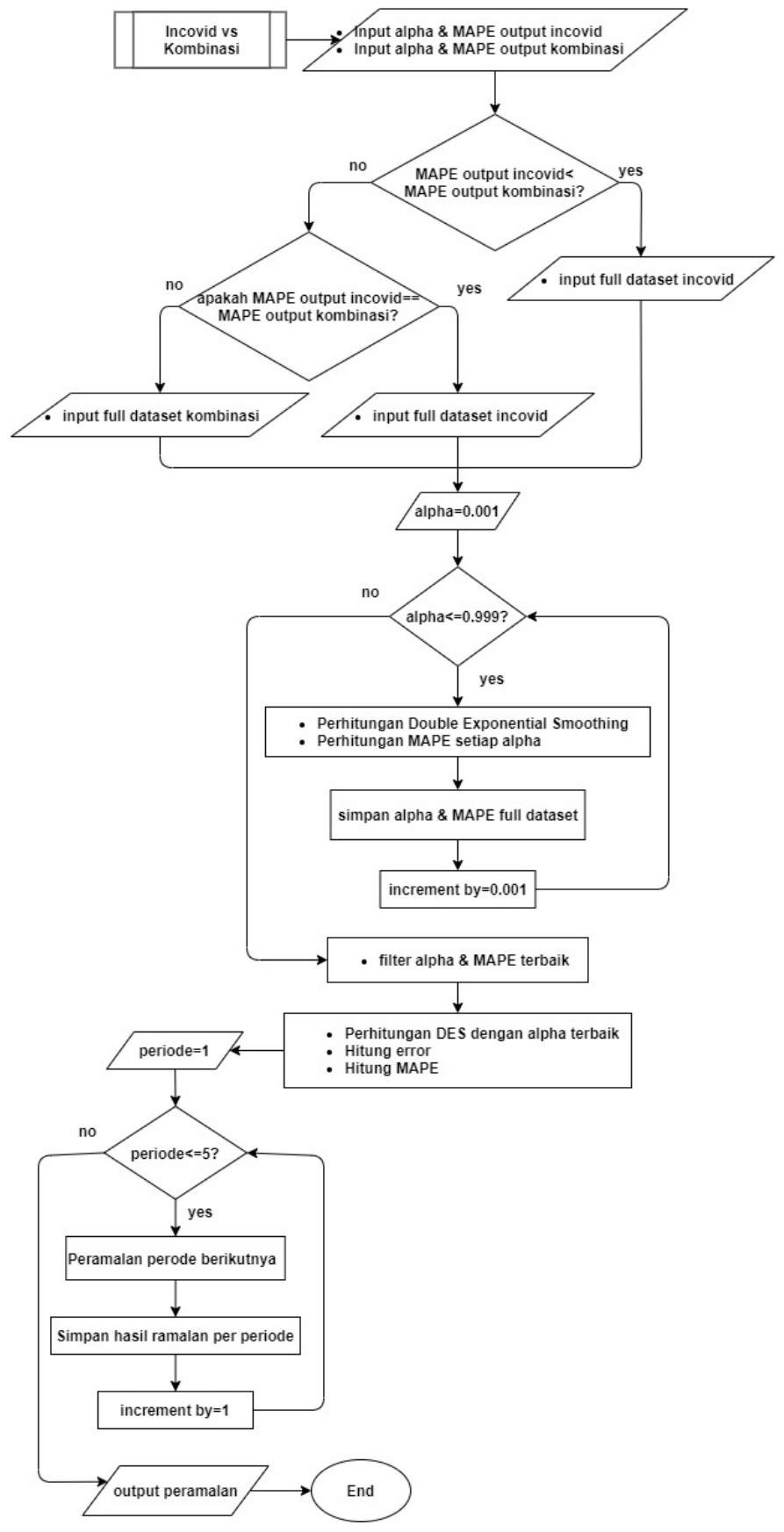

Gambar 4 Alur Incovid vs Kombinasi

Selanjutnya adalah rumus dari metode-metode yang digunakan dalam tahap Pemrosesan Data dan tahap Incovid vs Kombinasi :

a. Exponential Smoothing

Metode Exponential Smoothing merupakan prosedur perbaikan terus-menerus pada peramalan terhadap objek pengamatan terbaru [44]. Terdapat 3 jenis Exponential Smoothing, yaitu Single, Double, dan Triple. Namun pada penelitian ini hanya dibutuhkan metode Single dan Double.

1. Single Exponential Smoothing (SES) 


\section{KILAT}

Vol. 10, No. 1, April 2021, P-ISSN 2089-1245, E-ISSN 2655-4925

DOI: https://doi.org/10.33322/kilat.v10i1.1200

Digunakan apabila pola data tidak dipengaruhi pola trend atau musiman (acak). SES juga diterapkan pertama kali sebelum memasuki proses Double Expoenntial Smoothing. Berikut persamaannya:

$$
\mathrm{S}_{t}^{\prime}=\alpha * X_{t-1}+(1-\alpha) \mathrm{S}_{t-1}^{\prime}
$$

Dimana:

$\mathrm{S}_{\mathrm{t}} \quad$ : Nilai dari pemulusan pertama

$\alpha \quad$ : Nilai alpha yang telah ditentukan $(0<\alpha<1)$

$\mathrm{X}_{\mathrm{t}-1} \quad$ : Nilai aktual atau nilai sebenarnya

$\mathrm{S}{ }_{\mathrm{t}-1}$ : Nilai pemulusan pertama sebelumnya

\section{Double Exponential Smoothing (DES)}

Digunakan apabila pola data dipengaruhi trend namun tidak dipengaruhi oleh musiman. Berikut adalah persamaannya:

$$
\begin{aligned}
& S^{\prime \prime}{ }_{t} \\
& =\alpha * S^{\prime}{ }_{t-1}+(1 \\
& -\alpha) S^{\prime \prime}{ }_{t-1} \\
& \quad a_{t} \\
& =S^{\prime}{ }_{t} \\
& \quad+\left({S^{\prime}}_{t}-S^{\prime \prime}{ }_{t}\right) \\
& =2 S^{\prime}{ }_{t}-{S^{\prime \prime}}{ }_{t} \\
& b_{t} \\
& =\frac{\alpha}{1-\alpha}+\left(S^{\prime}{ }_{t}\right. \\
& \left.-S^{\prime \prime}{ }_{t}\right) \\
& F_{t}+m \\
& =a_{t}+b_{t} \cdot m
\end{aligned}
$$

Dimana:

$$
\begin{array}{cl}
{S^{\prime \prime}}^{\prime}{ }_{t} & : \text { Nilai pemulusan ganda } \\
S^{\prime}{ }_{t} & : \text { Nilai pemulusan tunggal } \\
S^{\prime}{ }_{t-1} & ; \text { Nilai pemulusan tunggal pada period eke }(\mathrm{t}-1) \\
\mathrm{S}^{\prime \prime}{ }_{t-1} & : \text { Nilai dari pemulusan ganda sebelumnya. } \\
\alpha & : \text { Parameter pemulusan eksponential, } 0<\alpha<1 \\
a_{t}, b_{t} & : \text { Konstanta pemulusan pada periode ke-t } \\
F_{t}+m & : \text { Hasil peramalan untuk periode ke depan } \\
m & : \text { Jumlah periode ke depan yang diramalkan }
\end{array}
$$

b. Mean Absolute Percentage Error (MAPE)

Digunakan sebagai metode untuk mengukur tingkat error peramalan. Berikut rumusnya [45]: 
Keterangan:

$$
M A P E=\frac{1}{n} \sum_{t=1}^{n}\left(\frac{|a-b|}{b}\right) \times 100
$$

a : Nilai aktual periode $\mathrm{t}$

b : Nilai peramalan periode $\mathrm{t}$

\subsection{Evaluation}

Pada tahap evaluasi tingkat MAPE pada setiap hasil peramalan Double Exponential Smoothing setiap dataset yang ada dan akan didapatkan hasil berupa metode mana yang terbaik dalam kasus prediksi harga emas Antam ini, serta dilakukan evaluasi ini untuk diketahui model mana yang terbaik.

\subsection{Deployment}

Pada tahap ini, penelitian akan dikembangkan untuk meningkatkan kualitas pemrosesan datanya. Pada tahap Deployment ini model dapat dikembangkan melalui otomatisasi model, pengembangan aplikasi, terintegrasi dengan sistem informasi manajemen, atau operasional yang ada [46]. Dalam tahap penelitian ini akan digunakan perangkat yang ada yaitu RStudio.

\subsection{Validasi Akurasi}

Validasi akurasi tidak termasuk kedalam tahapan CRISP-DM tetapi digunakan untuk mengukur tingkat akurasi dari hasil akhir penelitian. Untuk memvalidasi akurasi dari peramalan akan digunakan pengkategorian nilai MAPE [47], yaitu jika:

a. MAPE $<10 \%$, maka kemampuan peramalan sangat baik

b. MAPE $10 \%-20 \%$, maka kemampuan peramalan baik

c. MAPE $20 \%-50 \%$, maka kemampuan peramalan cukup/layak

d. MAPE $>50 \%$, maka kemampuan peramalan buruk

\section{HASIL DAN PEMBAHASAN}

Berdasarkan hasil pengujian metode dan model yang dilakukan diperoleh nilai perbandingan pada table 2 .

Tabel 2. Model terbaik DES

\begin{tabular}{|c|c|l|c|c|}
\hline Dataset & Range Tanggal & \multicolumn{1}{c|}{ Imputasi } & Bobot Terbaik & MAPE \\
\hline \multirow{2}{*}{ Pracovid-19 } & \multirow{2}{*}{$28 / 12 / 2015$ s.d. $29 / 2 / 2020$} & LOCF & 0,234 & $0,6024615 \%$ \\
\cline { 3 - 5 } & & linear interpolation & 0,245 & $0,5988028 \%$ \\
\hline \multirow{2}{*}{ Incovid-19 } & $2 / 3 / 2020$ & LOCF & 0,259 & $1,599885 \%$ \\
\cline { 3 - 5 } & s.d.18/6/2020 & linear interpolation & 0,277 & $1,614191 \%$ \\
\hline \multirow{2}{*}{ Kombinasi } & $28 / 12 / 2015$ & LOCF & 0,235 & $0,6682142 \%$ \\
\cline { 3 - 5 } & s.d. $18 / 6 / 2020$ & linear interpolation & 0,246 & $0,6655639 \%$ \\
\hline
\end{tabular}




\section{KILAT}

Vol. 10, No. 1, April 2021, P-ISSN 2089-1245, E-ISSN 2655-4925

DOI: https://doi.org/10.33322/kilat.v10i1.1200

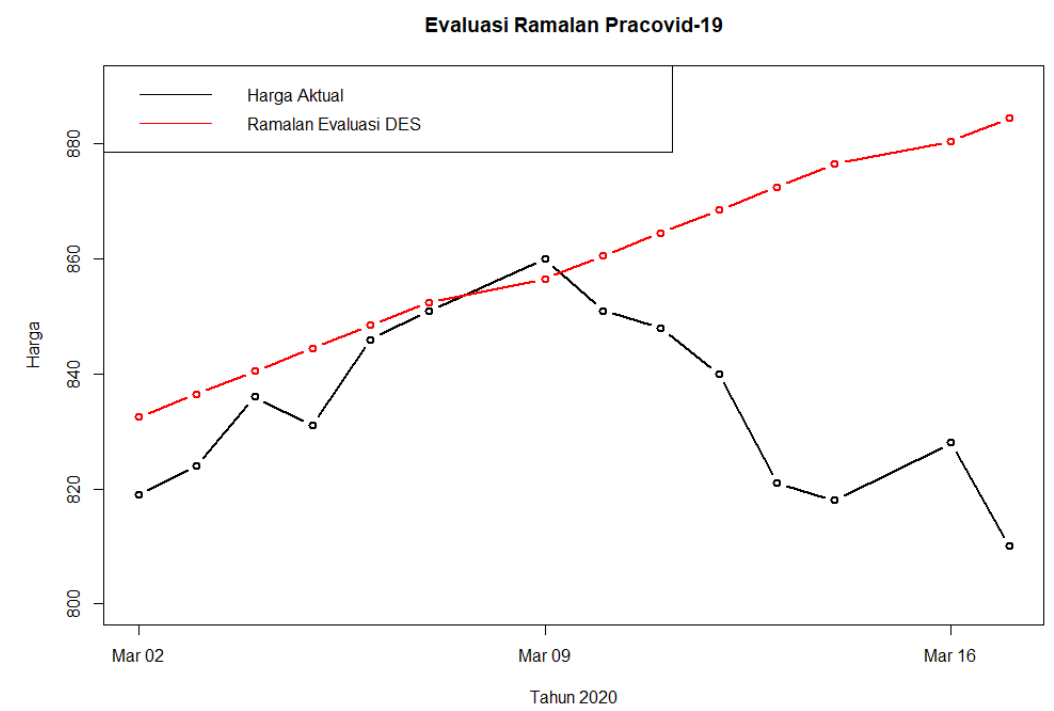

Gambar 5. Grafik evaluasi Pracovid-19
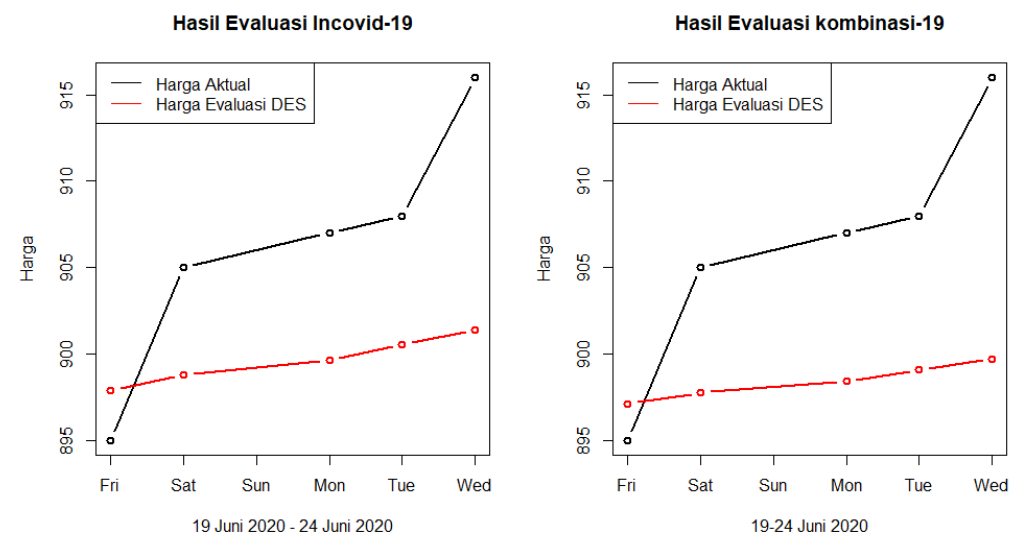

Gambar 6. Grafik evaluasi Incovid-19 dan Kombinasi-19

Tabel 3. Hasil evaluasi terbaik

\begin{tabular}{|l|c|l|c|c|}
\hline \multicolumn{1}{|c|}{ Dataset } & Range Tanggal & Imputasi Terbaik & Bobot Terbaik & MAPE \\
\hline $\begin{array}{l}\text { Pracovid-19 } \\
(14 \text { periode })\end{array}$ & $2 / 2 / 2020$ s.d. $17 / 3 / 2020$ & linear interpolation & 0,245 & $2,97268 \%$ \\
\hline $\begin{array}{l}\text { Incovid-19 } \\
(5 \text { periode })\end{array}$ & $19 / 6 / 2020$ s.d. $24 / 6 / 2020$ & LOCF & 0,259 & $0,848601 \%$ \\
\hline $\begin{array}{l}\text { Kombinasi } \\
(5 \text { periode })\end{array}$ & $19 / 6 / 2020$ s.d. $24 / 6 / 2020$ & linear interpolation & 0,246 & $0,949008 \%$ \\
\hline
\end{tabular}

Hasil evaluasi dataset: dataset Incovid-19 dengan hasil bobot alpha 0.259 dan MAPE(dalam persen) 0.848601 mampu meramalkan harga harian emas lebih $b$ aik daripada Kombinasi dengan hasil bobot alpha 0.246 dan MAPE(dalam perse n) 0.949008

Gambar 7. Output Incovid vs Kombinasi 


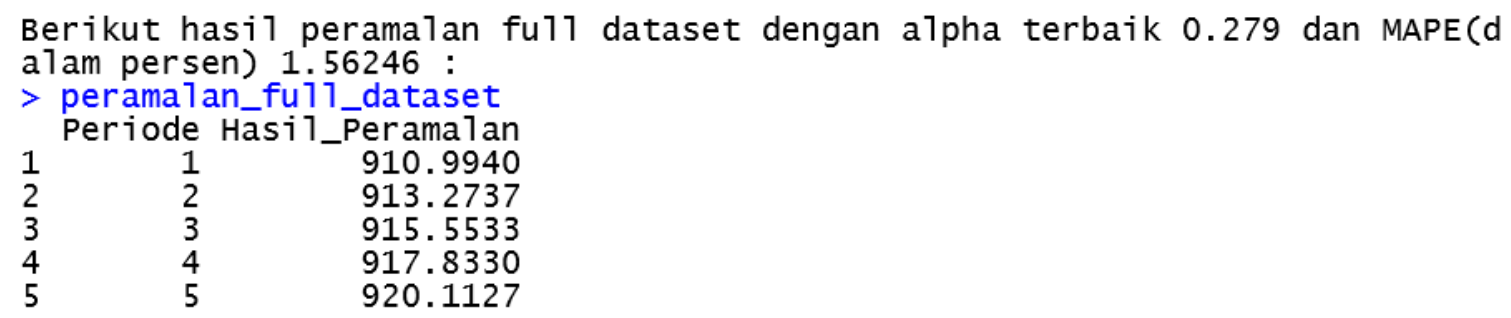

Gambar 8. Output model terbaik

Dari visualisasi Gambar 5 diketahui bahwa memang benar selama 2 minggu awal pandemi Covid-19 ini harga harian emas mengalami perubahan trend yang ekstrem tak terduga sehingga Double Exponential Smoothing sudah tidak sesuai lagi dengan keadaan di lapangan. Berdasarkan Tabel 3, visualisasi Gambar 6, dan Gambar 7 diketahui bahwa hasil evaluasi terbaik didapatkan oleh Incovid-19 berimputasi LOCF dibandingkan dengan Kombinasi dengan linear interpolation sehingga peramalan berikutnya menggunakan dataset penuh Incovid-19 dari tanggal 2 Maret 2020 hingga 24 Juni 2020 dan didapatkan hasil pada Gambar 8.

\subsection{Implikasi}

Dari hasil penelitian didapatkan 2 macam implikasi, yaitu implikasi teoritis dan implikasi praktis. Untuk implikasi teoritis, pemilihan metode peramalan dan metode imputasi yang tepat, serta pembagian dataset per peristiwa mampu meningkatkan kualitas peramalan yang semakin mendekati data aktual di lapangan. Sedangkan untuk implikasi praktis, variasi metode usulan dari penelitian ini dapat diadaptasi maupun dikembangkan kembali oleh para investor maupun peneliti.

\section{Kesimpulan}

Berdasarkan hasil penelitian, dapat ditarik kesimpulan bahwa Double Exponential Smoothing baik dengan imputasi LOCF dan linear interpolation cocok digunakan dalam peramalan harga harian emas Antam karena semua variasi datasetnya menghasilkan MAPE dibawah <10\% (kategori kemampuan meramal sangat baik). Pembagian dataset per peristiwa mempengaruhi dari segi jumlah rekam data maupun kemampuan pembacaan trend oleh Double Exponential Smoothing. Hal itu ditunjukkan dengan dataset Incovid-19 berimputasi LOCF merupakan dataset terbaik dalam penelitian ini karena memiliki hasil peramalan yang paling mendekati data aktual mesikipun memiliki rekam data paling sedikit (MAPE $=0.848601 \%$ ). Selain itu, peramalan Double Exponential Smoothing dengan jumlah rekam banyak lebih cocok menggunakan imputasi linear interpolation sedangkan untuk rekam data sedikit lebih cocok menggunakan imputasi LOCF.

\section{DAFTAR PUSTAKA}

[1] V. Lidyana, "Harga Emas dan Sejarahnya Hingga Kini Jadi Komoditas," detikFinance, 0507 2020. [Online]. Available: https://finance.detik.com/berita-ekonomi-bisnis/d-5080711/hargaemas-dan-sejarahnya-hingga-kini-jadi-komoditas. [Accessed 2912 2020].

[2] B. Lobel, "What is Gold? Understanding Gold as a Trader's Commodity," Gold Price , 2509 2019. [Online]. Available: https://www.dailyfx.com/gold-price/what-is-gold.html. [Accessed 2912 2020].

[3] A. Hayes and M. J. Boyle, "Why Gold Matters: Everything You Need To Know," Investopedia, $\quad 14 \quad 92020 . \quad$ [Online]. Available: https://www.investopedia.com/articles/economics/09/why-gold-matters.asp. [Accessed 2912 2020]. 


\section{KILAT}

Vol. 10, No. 1, April 2021, P-ISSN 2089-1245, E-ISSN 2655-4925

DOI: https://doi.org/10.33322/kilat.v10i1.1200

[4] A. Zaenudin, "Menambang Emas dari Perangkat Elektronik Kita," tirto.id, 91 2018. [Online]. Available: https://tirto.id/menambang-emas-dari-perangkat-elektronik-kita-cCW8. [Accessed 2912 2020].

[5] A. N, "Can Gold Prices Forecast the Australian Dollar Movements?," International Economics and Finance, pp. 75-82, 2014.

[6] K. Gilchrist, "Gold has surged due to the pandemic — and it could keep going. Here's what to know about investing now," A Division of NBC Universal, 1611 2020. [Online]. Available: https://www.cnbc.com/2020/07/20/investing-how-to-invest-in-gold-is-now-a-good-time-tobuy-gold. [Accessed 2912 2020].

[7] S. Zhou, K. K. Lai and J. Yen, "A Dynamic Meta-Learning rate-Based Model for Gold Market Forecasting," Expert Systems with Applications, 2012.

[8] Gold Forecast, "Gold Price," DailyFX, 2912 2020. [Online]. Available: https://www.dailyfx.com/gold-price. [Accessed 2912 2020].

[9] C. Aaron, "Gold Price 2021 Forecast: Continuation Advance Ahead," Latest Gold Price Forecast \& Predictions, 2412 2020. [Online]. Available: https://www.goldeagle.com/forecasts_predictions. [Accessed 2912 2020].

[10] J. Clark, S. Analyst and GoldSilver, "2020 Gold Price Forecast, Trends, \& 5 Year Predictions," Gold Silver, 2020. [Online]. Available: https://goldsilver.com/blog/gold-price-forecastpredictions/. [Accessed 2912 2020].

[11] The Economy Forecast Agency, "Gold Price Forecast For 2020, 2021, 2022, 2023 And 2024," Forecast Agency, 12 2020. [Online]. Available: https://longforecast.com/gold-price-todayforecast-2017-2018-2019-2020-2021-ounce-gram. [Accessed 202012 2020].

[12] R. S. Nugroho, "Rekap Kasus Corona Indonesia Selama Maret dan Prediksi di Bulan April," Kompas, $31 \quad$ Maret $2020 . \quad$ [Online]. Available: https://amp.kompas.com/tren/read/2020/03/31/213418865/rekap-kasus-corona-indonesiaselama-maret-dan-prediksi-di-bulan-april. [Accessed 2912 2020].

[13] T. Woodall, "Gold price set to lose momentum beyond pandemic after $28 \%$ increase in 2020," $\begin{array}{llllll}\text { S\&P } & \text { Global, } & 21 & 9 & 2020 . & \text { [Online]. }\end{array}$ https://www.spglobal.com/marketintelligence/en/news-insights/latest-news-headlines/goldprice-set-to-lose-momentum-beyond-pandemic-after-28-increase-in-2020-60056128. [Accessed 2912 2020].

[14] A. C. R and S. Sopia, "Menimbang Urgensi Berinvestasi Kala Pandemi," Republika, 114 2020. [Online]. Available: https://www.republika.id/posts/5837/menimbang-urgensiberinvestasi-kala-pandemi.. [Accessed 2912 2020].

[15] K. Safitri and B. P. Jatmiko, "Perhatikan Ini, Jika Ingin Investasi Emas Saat Pandemi Covid19," Kompas.com, $\quad 30 \quad 4 \quad 2020 . \quad$ [Online]. Available: https://money.kompas.com/read/2020/04/30/125434126/perhatikan-ini-jika-ingin-investasiemas-saat-pandemi-covid-19. [Accessed 2912 2020].

[16] Bisnis.com, "Baru Mau Investasi Emas di Masa Pandemi? 'Mending' Tahan Dulu!," Finansial.Bisnis.com, $22 \quad 52020 . \quad$ [Online]. Available: https://finansial.bisnis.com/read/20200522/55/1243657/baru-mau-investasi-emas-di-masapandemi-mending-tahan-dulu. [Accessed 2912 2020].

[17] L. A. Azanella and S. Hardiyanto, "Emas Cenderung Naik Saat Terjadi Ketidakpastian Ekonomi, Mengapa?," Kompas.com, 38 2020. [Online]. Available: https://www.kompas.com/tren/read/2020/08/03/125600165/emas-cenderung-naik-saatterjadi-ketidakpastian-ekonomi-mengapa-?page=all. [Accessed 2912 2020]. 
[18] I. Priyadi, J. Santony and J. Na'am, "Data Mining Predictive Modeling for Prediction of Gold Prices Based on Dollar Exchange Rates, Bi Rates and World Crude Oil Prices," Indonesian Journal of Artificial Intelligence and Data Mining, vol. 2, no. 2, pp. 93-100, 2019.

[19] M. Riazuddin, "Predicting Gold Prices Using Machine Learning," Gold Prediction Series, 15 5 2020. [Online]. Available: https://towardsdatascience.com/machine-learning-to-predictgold-price-returns-4bdb0506b132. [Accessed 2912 2020].

[20] A. Hatamlou and M. Deljavan, "Forecasting Gold Price using Data Mining Techniques by Considering New," Journal of AI and Data Mining, vol. 7, no. 3, pp. 411-420, 2018.

[21] "Methods and formulas for Double Exponential Smoothing," Minitab, 2019. [Online]. Available: https://support.minitab.com/en-us/minitab-express/1/help-and-how-to/modelingstatistics/time-series/how-to/double-exponential-smoothing/methods-and-formulas/methodsand-formulas/. [Accessed 2912 2020].

[22] SCRC SME, "Double Exponential Smoothing: Approaches to Forecasting : A Tutorial," NC State University, 251 2011. [Online]. Available: https://scm.ncsu.edu/scmarticles/article/double-exponential-smoothing-approaches-to-forecasting-a-tutorial. [Accessed 2912 2020].

[23] Logam Mulia, "Harga Emas," Logam Mulia, 2020. [Online]. Available: https://www.logammulia.com/id/harga-emas-hari-ini. [Accessed 202012 2020].

[24] H. Xu and I. Biogenidec, "LOCF Method and Application in Clinical Data Analysis," pp. 1-5, 2009.

[25] X. Liu, Methods for handling missing data, Vols. 978-0-12-801342-7, Elsevier Inc. All rights reserved., 2016.

[26] A. M. Bayen and T. Siauw, An Introduction to MATLAB ${ }^{\circledR}$ Programming and Numerical Methods for Engineers, Elsevier Inc. All rights reserved., 2015.

[27] A. Setiaji, "Machine Learning : Missing Value," 2018. [Online]. Available: https://mragungsetiaji.github.io/python/machine\%20learning/2018/08/23/machine-learningmissing-value.html. [Accessed 2912 2020].

[28] colab.research.google, "Bagian 1, Pengenalan Missing value," colab.research.google, [Online]. Available: https://colab.research.google.com/drive/1Z8HcT33Z8AqzGrfCnGJle4yEOE1Piugd. [Accessed 2912 2020].

[29] S. Z. Abidin, T. M. T. Jalal, F. A. Razali, N. H. Hassim and N. F. Haron, "Comparison on estimating Malaysia gold price via nonlinear prediction method and Box-Jenkins model," in AIP Conference Proceedings 1974, 020057 (2018), 2018.

[30] S. Hansun, "A New Approach of Brown's Double Exponential Smoothing Method in Time Series Analysis," Balkan Journal of Elekctrical \& Computer Engineering, vol. 4, no. 2, pp. 7578, 2016.

[31] S. Hansun and Subanar, "H-WEMA: A New Approach of Double Exponential Smoothing Method," TELKOMNIKA, vol. 14, no. 2, pp. 772-777, 2016.

[32] B. Abraham and J. Ledolter, "Regression and Exponential Smoothing Methods to Forecast Nonseasonal Time Series," Statistical Methods for Forecasting, pp. 79-134, 2008.

[33] D. Mavridis, G. Salanti, T. A. Furukawa, A. Cipriani, A. Chaimani and I. R. White, "Allowing for uncertainty due to missing and LOCF imputedoutcomes in meta-analysis," Statistics in Medicine, pp. 1-18, 2018.

[34] D. Banerjee and A. Ghosal, "A Novel Technique to Utilize Geopolitical Risk as a Factor for Predicting Gold Price," in Computational Intelligence and Machine Learning, Proceedings of 


\section{KILAT}

Vol. 10, No. 1, April 2021, P-ISSN 2089-1245, E-ISSN 2655-4925

DOI: https://doi.org/10.33322/kilat.v10i1.1200

the 7th International Conference on Advanced Computing, Networking, and Informatics (ICACNI 2019), 2019.

[35] D. M. North, Data Mining for the Masses, Global Text Project 2012, 2012.

[36] A. Andiojaya and H. Demirhan, "A Bagging Algorithm for the Imputation of Missing Values in Time Series," Expert Systems with Applications, pp. 10-26, 2019.

[37] R. J. A. Little and D. B. Rubin, Statistical Analysis with Missing Data, New York: J. Wiley \& Sons, 1987.

[38] T. Hendrawati, "Kajian Metode Imputasi dalam Menangani Missing Data," in Prosiding Seminar Nasional Matematika dan Pendidikan Matematika UMS, Surakarta, 2015.

[39] Muflihah and R. Y. Pahlawan, "Perbandingan Teknik Interpolasi Berbasis R dalam Estimasi Data Curah Hujan Bulanan yang Hilang di Sulawesi," Puslitbang BMKG, Jakarta, 2017.

[40] T.-T.-T. Phan, É. P. Caillault, A. Lefebvre and A. Bigand, "Dynamic Time Warping-Based Imputation for Univariate Time Series Data," Pattern Recognition Letters, pp. 2-11, 2017.

[41] M. D. Bordo and F. Capie, Monetary Regimes in Transition, Cambridge University Press, 1993.

[42] R. J. Hyndman and G. Athanasopoulos, Forecasting: principles and practice, Otexts, 2013.

[43] M. I. J. Lamabelawa, "Analisis Perhitungan Metode Interpolasi pada Data Time Series Kemiskinan di NTT," Jurnal HOAQ-Teknologi Informasi Vol. 8,, pp. 640-646, 2018.

[44] S. Makridakis, S. C. Wheelwrigh and V. E. McGre, Metode dan aplikasi peramalan, Jakarta: Erlangga, 1999.

[45] R. Adhikari and R. K. Agrawal, An Introductory Study on Time Series Modeling and Forecasting, Cornell University, 2013.

[46] J. Suntoro, Data Mining : Algoritma dan Implementasi dengan Pemrograman PHP, Jakarta: PT. Elex Media Komputindo, 2019.

[47] P.-. C. Chang, Y.-. W. Wang and C.-. H. Liu, "The Development of A Weighted Evolving Fuzzy Neural network for PCB Sales Forecasting," Expert Systems with Applications 32, p. 88, 2007. 